\title{
ECLECTICISM STYLE IN ARCHITECTURE OF KHEDIVIAN CAIRO
}

Received January 22nd, 2018 | Accepted March 26th, 2018 | Available online December 15th, 2018| DOI: http://dx. doi. org/10.18860/jia.v5i2.4747 |

\section{Mohamed Enab}

Fayoum University, Egypt

E-mail:maa25@fayoum.edu.eg
Islamic Department, Faculty of Archaeology,

\begin{abstract}
Eclecticism style is one of the European architectural styles that have appeared in the buildings of Cairo in 13-14 A.H / 19-20A.D, which means the trend toward consolidation of various models and buildings in the previous civilizations and merge them and out in one building. This style has known as quoted-style or trend in architecture or eclectic architecture. The research is an attempt to Inventory these buildings that are built on this architectural style. This research follows the historical approach to knowing the origin of this architectural style and how it moved and spread in Cairo architecture in 1314 A.H / 1920 A.D. Then follows a descriptive and analytical approach of examples of these buildings built on this style, and analysis its architectural and artistic elements. In the end, the research has reached some critical results. For example, the primary purpose of this quotation and transportation is to give historical and technical value to these monuments. But unfortunately, the method of this quotation came in the wrong way. Thus losing the principle of unity and harmony that characterized the Islamic architecture, they unwittingly distorted the heritage value. These buildings became a collection of models that are not harmonious.
\end{abstract}

\section{KFYWORDS:}

Eclecticism; Baron Palace; Egyptian museum; Gezira Palace

\section{INTRODUCTION}

In the past, the identity of people's architecture was clear and reflected the characteristics of these peoples and their environmental and social advantages. Today, this identity has disappeared because of the Western concepts. The West has become the source of our thinking and our direction, but this is the year of life and the law of evolution. Nations and people take form each other. But what is surprising is that the author, as a receiving person, is no longer able to analyze the data and explain it carefully to select benefit of them to achieve the right balance between imported and inherited influences. Taking advantages of their technologies and developments and integrating them with our history, finding our own architectural identity. Contemplation of contemporary Egyptian architecture reveals that there are architectural forms that have spread in all cities influenced by the style and ideas of Western architecture and its schools [1]. These forms reflect the traditions and customs of western societies that are far from our Islamic values and principles derived from
Islamic law. These forms also illustrate that Egyptian architecture is a mixture of different styles, such as what is influenced by heritage architecture, including what is transmitted from the Western architecture that invaded and took control of the architectural environment. Westernization became a principle symbolizing progress and development. Hence, Egyptian architecture lost its identity through the loss of its components stemming from the Islamic values and expressive of the natural environment, social, and even climate [2].

This research attempts to answer for an essential and pivotal question which caused the spread of this model in Egyptian architecture during that period. Did this style lose the identity of the distinctive Egyptian architecture in that period? In order to answer this question, some specific objectives have been formulated and identified, which, through this study, can reach the answer to the previous question:

1- Definition of this style, and most important factors that influenced in a spread of it.

2- Study examples and models of buildings built 
on this style in Cairo.

\section{THE DERNIION OF ECLECTICISM STYL}

It is one of the Western European architectural styles that spread in buildings of the capital of Egypt (Cairo). Eclecticism is meant the trend towards the collection of different models of previous civilizations and merges them and put them all in one building. The architect collects from different architectural models or artificial elements that may be part of a roof, entrance, hall, interior courtyard, façade or arcade of arches and others, then put them together in the same building according to his taste and the owner's desire for the building [3] [4] [5]. From here it can be called assembly or non-direction in architecture.

Eclecticism style has appeared in many of the buildings, especially in the second half of the 19th century, in many of the palaces of Mohamed Ali Pasha's family [6]. Eclecticism is a trend in architecture, sculpture, and photography appeared in the midnineteenth century when modernity pioneers of architecture sought to free themselves from the stresses of the classical and the importance of the creative (romantic) from this time till the Middle Ages. These pioneers called themselves selective or eclectic [7].

The use of the term eclecticism or selectivity has long been used and replaced by another concept, which is the architecture of historical methods or historical term (Historism) [8][9]. Selective and historical proponents have chosen elements of ancient architecture and combined them into one work with a new synthesis not interested in the role of every part has in formulating the features of the method to which it originally belongs [10]. This style appeared in some countries in Western Europe, America and Russia between 1830 and 1850 and continued until the first decade of the 2oth century [11]. It is a mixture of various European styles such as the new classical style, neo-baroque style, and modern art [12].

The term eclecticism is derived from the Greek word $\kappa \lambda \varepsilon \kappa \tau$ เkó -eklektikos, meaning "the ability to choose, the choice of the best, to choose". This term is defined in Arabic as either electoral or selectivity. This style is characterized by several names like eclecticism, selective architecture, non-direction in architecture, eclectic architecture, and collective style.

Beginning of using of this term dates back to philosophers, it has different meanings for them as a combination of some doctrines of many philosophies and the appropriateness between them [10]. It is an eclectic style of various elements and patterns related to its function and place them in one building. Eclecticism aims at electing elements of previous historical architectural and artistic styles and syntactically preparing them to create a new work [13]. The most accurate definition of Eclecticism style is the word by Fedor Dostoevskii. $\mathrm{He}$ is one of the architectural historians in 1873 that mentioned the form of European architecture in the 19th and early 20th. He said that people could not define our current architecture, it is a sort of chaotic mess entirely, and appropriate to the disorder of the present moment [14]. Cézar Denis Daly (1894-1811) expressed Eclecticism as a summary of the ideas of previous civilizations.

The reason for the creation of this style was the growing concern of many architects that resulted from their dissatisfaction with trying to imitate the Greek and Gothic styles as one of the most elegant models since the process of revival in Europe. Therefore, some of these architects returned to the architecture of the Renaissance, while others tried to search for other models to Imitate them, such as Islamic and Indian style and others, This resulted finally in the appearance of Eclecticism style. So, we find that most of the buildings in the 19th and early 2oth shared in several models at the same time. This style is considered to be one of the most elegant and widespread styles of architectural trends in Europe at that time [15] (Figure (1)).

The Islamic world began to imitate Western architecture especially since early 19 th considering this as a manifestation of European civilization. As a result, they were interested in form, style, columns, and cornices, not with its real content, function, and purpose. The architecture thus became details taken from different European styles. Therefore, this style is known as Eclecticism because it contains elements of multiple models without relying on a particular style have its specific characteristics. This style, however, has shown the craftsmanship of the architect and display of his Science and knowledge in his choice between different architectural and decorative details that he chooses according to his hobby and by the wishes of the owner; he covered buildings like clothes or disguised masks [16].

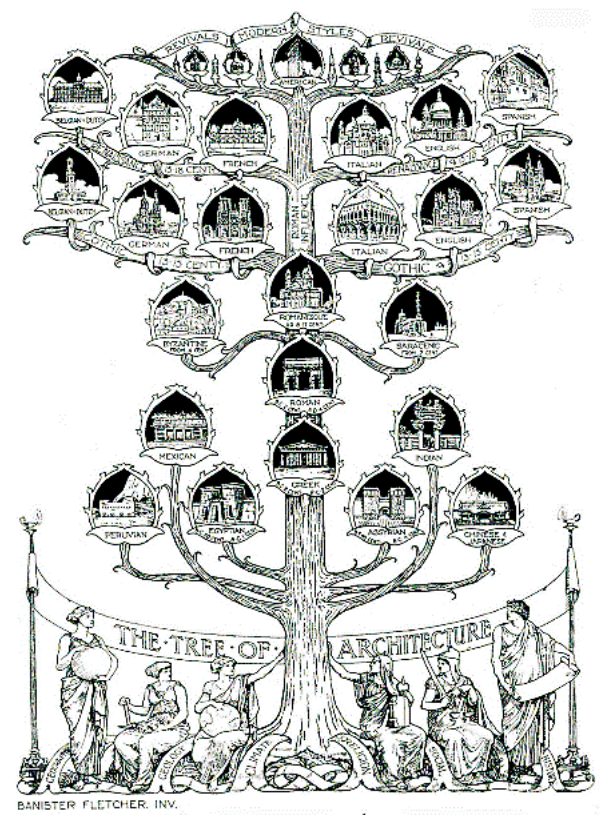

Figure 1.

The tree of architecture, an explanation of the different architectural styles which eclecticism style quoted architectural elements and decorative details and put them in one building [17]

84 | Journal of Islamic Architecture, 5(2) Desember 2018 
Eclecticism style moved with all the European styles that spread in Cairo in 13 AH/19 A.D; it spread in many buildings of Cairo and north, upper Egypt in 1314AH/19-20 A.D. In Cairo, it appeared primarily in the neighborhoods of Zamalek, Garden City, and Heliopolis [7]. Some factors led to the transfer of European styles to Egypt, such as:

a. Foreign campaigns against Egypt represented in the French campaign on Egypt from (12131216 A.H/1798-1801 A.D), and the British occupation from 1299-1372 A.H/1882-1952 A.D). These periods of the history of Egypt is called Westernization which led to the loss of Islamic architectural and artistic identity in Egypt. These campaigns helped to transfer many of the European architectural and artistic influences to Egypt.

b. Turkish origin of Mohamed Ali and his family and their tendencies to the West, they followed opening policy to the west, which has its harmful effect on the spread of the European architectural and artistic styles in the Egyptian artistic and architectural activity slowly until it finally overwhelmed the Islamic style.

c. The foreign communities of different races of Europe, which accompanied the French and English colonialism, they also helped to transfer these European influences to Egypt. The impact of these communities has become attention of the ruling authority - examples of architects of these communities Italian Alfonso Mancolo, French de Correl, Del Russo, and many others. They carried out their architectural activities in Egypt, some of whom even held senior government positions, such as Julienz Frantz, who was the chief architect of the Khedive Ismail Pasha, and Alfonso Mancolo, who was the primary architect of the Egyptian government.

d. The cultures of European society influenced the scientific missions that Mohammed Ali and his family were keen to send to Europe which created a generation of intellectuals. They imitated these European styles to replace them with local Islamic styles.

e. These European styles are characterized by rapid implementation compared to ArabIslamic styles. They also need fewer expenses in their application compared to the enormous costs is necessary by Islamic buildings which contain accurate drawings and artistic forms.

\section{HISTORY OF THE ECLECTICISM STYLE IN ARAB ISLAMIC ARC HITECTURE}

The emergence of Eclecticism in this term, which appeared in Europe during the beginning of the 19th century, is much older than this date since it was known from ancient times in various periods and old ages. The term "Eclecticism" is relatively modern and a literal translation of this trend, which appeared in Europe in the 19th century, where the previous civilizations were quoted from each other. Where the phenomenon of the influence of prior arts not only due to Islamic art, but it is a global phenomenon, all the arts quoted from prior arts. As all civilizations are a continuum, and the more it is possible to quote and derive its difficulties, the higher the instinct of innovation. Since its inception, Islamic architecture has quoted details and various architectural and artistic influences from previous civilizations. It has also moved some of the pieces, elements and architectural units of ancient buildings and their architectural status together in one building [18].

It is known that Muslims at first did not have their art, but after Islamic conquests, they encouraged fine arts in this country and brought building materials and brought skilled workers from different countries. When analyzing these elements and units, we find them due to the civilizations before the Islamic architecture, whether the Greek, Byzantine, Sassanian or Coptic civilization and others. In spite of the importance of previous civilizations, it does not underestimate the value of the Muslim artist from which he was quoted which has become a unique and distinct personality with new characteristics [19][20]. The idea of citation and transfer from previous civilizations continued throughout the historical ages until the 19th century. Examination of the buildings designed according to the different European styles which moved to Egypt during the Mohamed Ali Dynasty. Most of these buildings are created according to Eclecticism style, as these buildings combine several different architectural styles, although dominated by one style.

\section{CRTIC ISM OF THIS ECLECTICISM STYLE}

This style was adopted to take an element of each style and use it in one building [21], the building became very strange as well as the use of Eclecticism style considered a misuse of the concepts of historic buildings. Also, it leads to the ignorance of the people in the architectural culture. Although diversification is required in architecture regarding material, color, texture, lengths, shape, openings, walls and others with no exaggeration, and as not to diverge the parts and contradict, so it should remain the diversification in the unit. Then, two important concepts must be identified the change and development in architecture. First, the change is meant to depart from the usual shape. Second, the development is to create additions that are compatible with the developments. What happened in the successive Islamic eras is a natural and spontaneous development as a result of the accumulated experience, but what happened in the period of Mohamed Ali's family in Egypt and what happened in the rest of Muslim world is a radical change in the shape and nature of governance. It came not only at once but in successive stages culminating in the era of Khedive Ismail in the last of the 19th century. Finally, it crystallized in the form that led to losing Islamic architecture its identity in the 2oth century. Therefore, some architects considered the 19th 
century is the worst era in the architectural field as interest by the cultures of ancient ages led to move between styles and quote from everywhere without unified and distinctive style for this period.

\section{THE GENERAL SURVEY OF BUILINGS BUILTIN ECLETICISM IN CAIRO}

Eclecticism Style has spread widely in all kinds of Cairo buildings. And whole neighborhoods and streets came by Eclecticism Style especially in the forms of facades and architectural, decorative elements derived from different architectural styles. Neighborhood Heliopolis is considered one of the most famous of these neighborhoods constructed on Eclecticism [22]. It was founded by businessman Edward Amban who used his architects Jasper and Alexander Marcel, who worked to achieve architectural renaissance and great diversity in the use of Moroccan, Mamluk, Japanese, Indian, Italian, French and Roman architectural styles [23]. Architectural and decorative elements of buildings located in the main streets of Heliopolis borrowed from various sources. Some of them are oriental elements in general, and some of them are just geometric shapes whose origin cannot be traced back to any historical style. But the vast majority was directly derived from elements of various Islamic ages such as Fatimid, Mamluk, and Ottoman which were accurately quoted and mixed. Although these Islamic details, none of the Heliopolis buildings represented an attempt to reconstruct archaeologically or re-create any historical period. The columns, pillars, decorative friezes, and balconies are no more than mutual elements in the architectural vocabulary, whether Ottoman or Mamluk, the lesson was how they were placed in the façade, and its relation to the areas without adornment around it. Also, by its reproduction or repetition that creates rhythm. Therefore, the architecture of Heliopolis is involved in many aspects of the Art Nouveau movement as it shares with the historical Islamic architecture [24]. The most beautiful buildings of central Cairo were built in Eclecticism style [25]. This style appeared in a different kind of architecture in Cairo like religious, residential and commercial and others. The survey of the remaining models of this style is shown in Table 1.

Table 1. Indicated Examples of remaining buildings designed on Eclecticism style in Cairo that its dates of construction, locations, names of its architects and architectural styles influenced in it

\begin{tabular}{|c|c|c|c|c|c|}
\hline Name & DATE & KIND & LOCATION & ARCHITECT & $\begin{array}{l}\text { ARCHITECTURAL } \\
\text { STYLES }\end{array}$ \\
\hline $\begin{array}{c}1- \\
\text { Al-Jazeera palace }\end{array}$ & 1864-1869A.D & Residential & $\begin{array}{l}\text { Zamalek neighbor- } \\
\text { hood }\end{array}$ & $\begin{array}{l}\text { Julius Franz } \\
\text { Pasha }\end{array}$ & $\begin{array}{c}\text { European style with } \\
\text { some Islamic influences } \\
\text { of Moroccan and Anda- } \\
\text { lusian }\end{array}$ \\
\hline $\begin{array}{c}\text { 2- } \\
\text { The Ex. Club Risotto } \\
\text { (Suares Building) } \\
{[12]}\end{array}$ & 1897 A.D & $\begin{array}{l}\text { New clubs and } \\
\text { restaurants }\end{array}$ & $\begin{array}{l}3 \text { Maidan Mustafa } \\
\text { Kamil }\end{array}$ & Antonio Lasiac & $\begin{array}{l}\text { Italian new classic Style } \\
\text { and style of Mediterra- } \\
\text { nean architecture }\end{array}$ \\
\hline $\begin{array}{c}3- \\
\text { Egyptian Museum } \\
\text { Al- Tahrir Square }\end{array}$ & 1897-1902 A.D & Scientific Museum & $\begin{array}{c}\text { in Mariot Pasha } \\
\text { Street in Al- Tahrir } \\
\text { Square }\end{array}$ & Marcel Dornin & $\begin{array}{c}\text { Neo-classical style and } \\
\text { elements of Pharaonic } \\
\text { styles }\end{array}$ \\
\hline $\begin{array}{c}5^{-} \\
\text {Saint Joseph } \\
\text { Church of French } \\
\text { Catholic [12] }\end{array}$ & 1904 A.D & Religious & $\begin{array}{l}102 \text { Mohamed Bey } \\
\text { Farid Street (New } \\
\text { Church St) }\end{array}$ & Aristide lenori & $\begin{array}{c}\text { Italian Romanesque } \\
\text { style, Gothic style and } \\
\text { elements of the Islamic } \\
\text { style }\end{array}$ \\
\hline $\begin{array}{c}4^{-} \\
\text {The building of fire } \\
\text { station }[12]\end{array}$ & $\begin{array}{l}\text { After } 1906 \\
\text { A.D }\end{array}$ & Public & Attba square & $\begin{array}{l}\text { Sicily Giuseppe } \\
\text { Garozo and his } \\
\text { sons after him }\end{array}$ & $\begin{array}{l}\text { New classic and Gothic } \\
\text { style }\end{array}$ \\
\hline $\begin{array}{c}5- \\
\text { Palace of the Baron } \\
\text { Emban }\end{array}$ & $\begin{array}{l}1906-1909 \\
\text { A.D }\end{array}$ & Residential & Heliopolis & $\begin{array}{l}\text { Alexandre Mar- } \\
\text { cel- decorated } \\
\text { with Georges- } \\
\text { Louis Claude. }\end{array}$ & $\begin{array}{l}\text { the Indian temples } \\
\text { (Cambodian style) and } \\
\text { elements of the Gothic } \\
\text { and Islamic style }\end{array}$ \\
\hline $\begin{array}{c}\text { 6- } \\
\text { Al- Imarat al- } \\
\text { Khidiwiya (the } \\
\text { khedivial building) } \\
{[25][26]}\end{array}$ & 1911 A.D & Residential & $\begin{array}{c}\text { 11-14-15 Emad El-din } \\
\text { St. }\end{array}$ & $\begin{array}{l}\text { Antonio Lasiac, } \\
\text { Gustav } \\
\text { Broucher, and } \\
\text { Gougez Park }\end{array}$ & $\begin{array}{l}\text { Art Noveau, Neo- } \\
\text { Baroque- style of Medi- } \\
\text { terranean architecture- } \\
\text { the influence of the } \\
\text { French School of Fine } \\
\text { Arts [26]. }\end{array}$ \\
\hline $\begin{array}{c}7- \\
\text { Shorbagi Building } \\
\text { (formerly San Da- } \\
\text { vid's Bryan Build- } \\
\text { ing) }[12]\end{array}$ & 1911 A.D & $\begin{array}{l}\text { Residential and } \\
\text { Commercial }\end{array}$ & $\begin{array}{l}16 \text { Adly St. overlook- } \\
\text { ing Mohamed Bey } \\
\text { Farid Street and } \\
\text { Abdel Khalek Thar- } \\
\text { wat St. }\end{array}$ & Robert Willems & $\begin{array}{l}\text { Neo-Baroque and neo- } \\
\text { gothic style. }\end{array}$ \\
\hline
\end{tabular}




\section{AN ANALYTICALSTUDY OF FAMOUS BUIDINGS BUILTIN ECLECTICISM STYL IN CAIRO}

The researcher will study three examples of the buildings constructed in Eclecticism style. Namely, AlJazeera palace in Zamalek, the Egyptian Museum of AlTahrir Square, and the Baron Palace in Heliopolis. The Identification data of Al Jazeera Palace described as following in Table 2.

Table 2: Identification Data of Al- Jazeera palace in Zamalek. Cairo [27]

\begin{tabular}{lll}
\hline \multicolumn{3}{c}{ Al- Jazeera palace in Zamalek (Figure 2) } \\
\hline Archeological number: & $\begin{array}{l}\text { Date of construction: } \\
\text { None }\end{array}$ & $1869 \mathrm{AD} / 1386 \mathrm{AH}$ \\
\hline Creator Name: Khe- & Kind: Residential - Palac- \\
dive Isma il & es & \\
\hline Status of Monument: & Adminis- & Archaeo- \\
exit & trative & logical \\
& Area: Za- & Area: Za- \\
& malek & malek \\
\hline
\end{tabular}

The palace is built by the Khedive Ismail, located in the Zamalek quarter (Figure 3). It was made after his visit to Berlin in December 1863, where he was impressed by a villa that was built there. He used architects on their heads Karl von Deptchen who built the villa of Berlin, for the design and decoration of this palace. He chose the most beautiful sites on the streets of Cairo and its parks to build in where a meeting of Abdeen Palace and the Saladin Citadel and Shoubra palace (Figure 4).

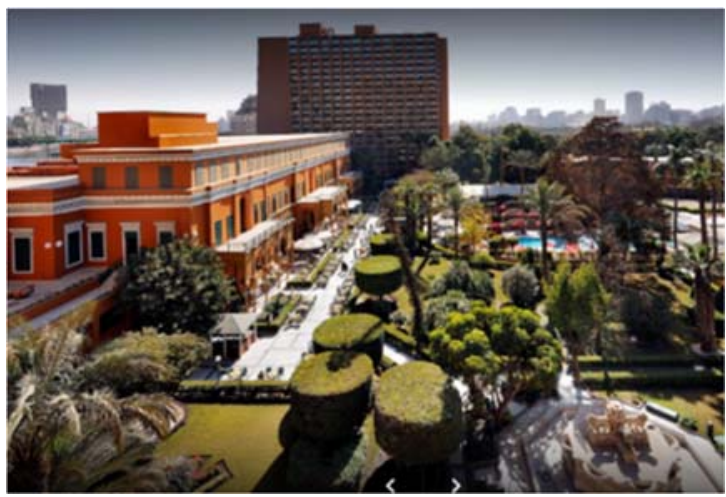

Figure 2. General view of Al-Jazeera palace in Zamalek (currently Marriott Hotel). Source: the Author.

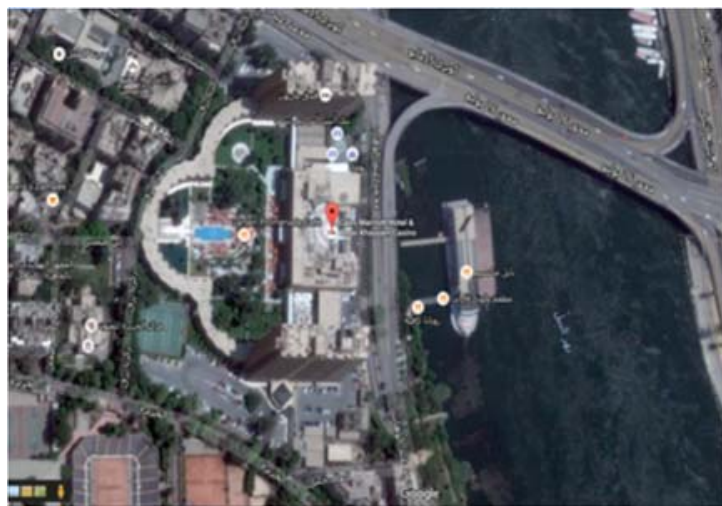

Figure 3. A map showing the site of Al-Jazeera palace in Zamalek (currently Marriott Hotel). Source: Google Earth.
The purpose of construction of this palace was to host the guests who will attend the opening ceremony of the Suez Canal, headed by Empress Eugenie. It has witnessed the largest and most spectacular celebrations in the modern age, where four sons of Khedive Ismail were married in one day. The Swiss company Bahar bought this palace and all surrounding lands. It began to divide and sell these lands and transformed the castle into a hotel. And then the palace was ownership to a wealthy Lebanese called Lotfallah until the imposition of the guard in 1961; it became a hotel following the Egyptian Hotels Company, which transformed its name to Omar Khayyam.

So the palace became state property. In 1985 , the company established a new hotel Follow to Marriott and has developed new buildings in the gardens of the palace. Also, it added two floors to the palace which consisted of three floors taking Ushaped. Figure 5 shows that the palace consists of three main sections, the Haramlak, and the small Salamlik, also the great Salamlik.

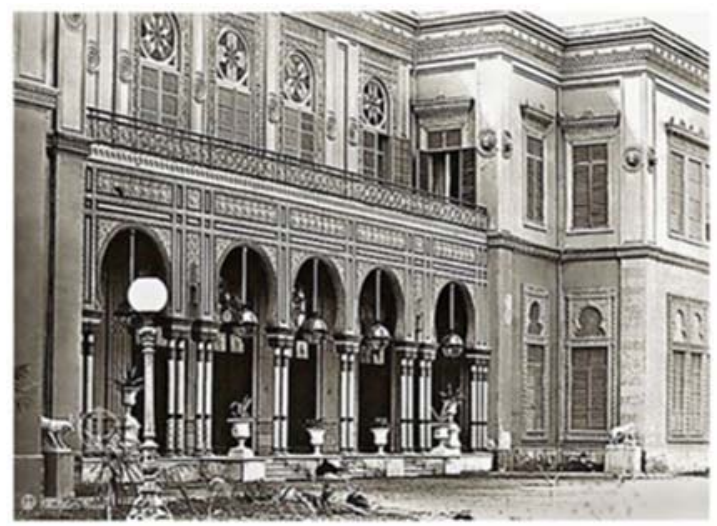

Figure 4. Al-Jazeera palace in Zamalek - an archival image showing Detail of the cast-iron portico of one of the façades and showing Moroccan influences. Source, http://faroukmisr.net/

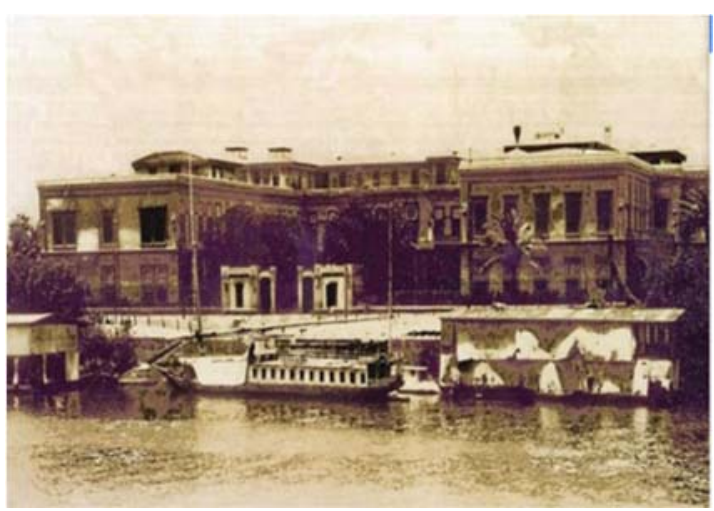

Figure 5. Al-Jazeera palace in Zamalek - an archival image showing the original palace taken U-shaped design of it. Source, http://faroukmisr.net/

The façades of the palace were characterized by the fine elements of the Andalusian architecture and the Arabic-Islamic motifs which were mixed with the ancient Greek and Roman decorations. 


\section{FATURES OF THE ECLEC TICISM STYLE IN AL- J AZIERA PALACE IN ZAMALEK}

The layout and style of this palace combine between several architectural styles. The first of these styles influenced the shape of this palace is Neo-Islamic style. It was designed by the German architect (Julius Franz Pasha) who was the chief architect of the office of Awqaf then. He was a lover of the Andalusian style. It was clearly illustrated in his design of this palace, in its facades which were characterized by the fine elements derived from Andalusian architecture where this palace was built on the example of Alhambra palace in Andalusia [28][29][30]. The influence of the Andalusian style has appeared in: using horseshoe arches, spiral columns which made of iron, and plaster castings as in Figure 6 . The architect also used the iron arcades that advance the facades of the Salamlik building which remind us of your surroundings around Court of the Lions in Alhambra Palace in Granada also, appeared in and in metal balustrade on the ground floor and the stucco decorations throughout the palace (Figure 7).

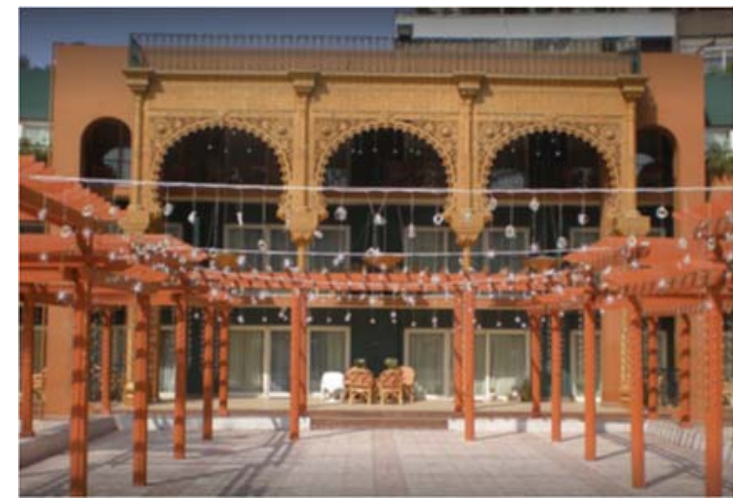

Figure 6. Al-Jazeera palace in Zamalek - One of the metal arcades, arched by horseshoe arch, clearly shows Andalusian influences. Source : http://faroukmisr.net/

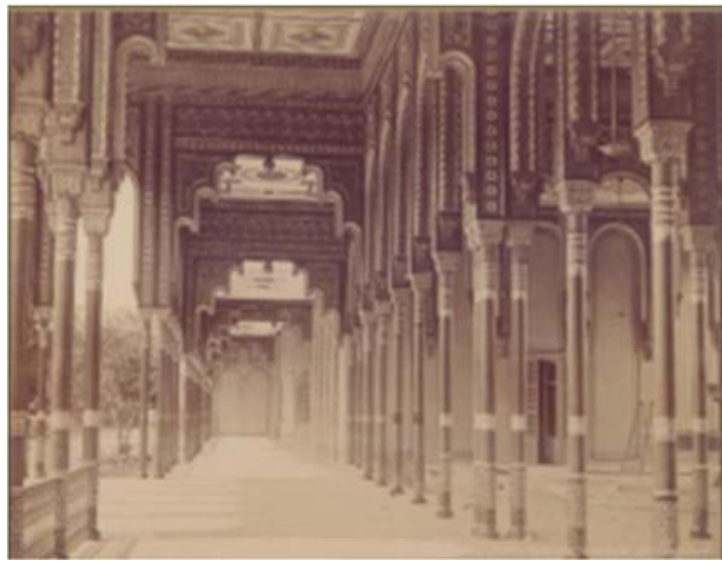

Figure 7. Al-Jazeera palace in Zamalek - arcades advanced the facades from the exterior, showing The Moroccan-Andalusian influence Source: http://modernegypt.bibalex.org

NewViewer.aspxalbumName $=$ IM 1547\&currentlmage $=$ IM 42818 \&Imagelndex $=1$

The second style appeared in the palace the Rumi (Turkish Rumi), which began to spread in Egypt since the reign of Muhammad Ali. And the interior design combines the Rumi style and European styles of palaces in that era. The reason for the presence of more than one architectural model in this palace is the large number of architects and artists who designed it and the diversity of their nationalities, where the general design by the Austrian architect Julius Franz Pasha and the German architect Karl von Debutch executed ironwork, gilding and interior decoration which cost LE 1100. The Italians Ernesto Vercucci and Angelo Arcolani also performed decorations of the palace. And the primary supervisor of the castle is Hassan Bey Noureddine.

Dilchivalry describes the great Salamlik's word: "It is more than 100 meters long topped by several columns engraved with the finest Arabic inscriptions, In the middle of this palace is a spacious hallway, which has nothing to hide from the sky. Its land is paved with marbles, including an ancient fountain, in one of the two wings of the palace rooms furnished with the most beautiful and decorated furniture". According to Timothy Mitchell, the design of some rooms in this palace is similar to the design of the rooms of the Tuileries Palace in France. The Khedive Ismail wanted to design this palace to combine the Cairo thousand night and night, which the Europeans liked in the nineteenth century in the design of the façade of the Islamic style. He would love to win the hearts of Europeans in the construction of buildings showing the extent of his loyalty to European civilization in following the European design of the interior of the palace [31].

Some of the references are classified as AlJazeera only under the Islamic model, the researcher agrees that this palace has many Islamic influences, but also it is included some other European models, so we have to put it in buildings designed according to them. It is also possible to say that the new Islamic style itself is considered Eclecticism style, where many of buildings designed in the Islamic style in the nineteenth century was not associated with an Islamic architectural style belongs to a particular period or a specific country. But there is a building combines elements of architectural and artistic from different periods and from different countries where the aspects of Andalusian architecture meets the Fatimid, Mamluk, and Ottoman.

Therefore the same building may have a different architectural and artistic elements from different periods and countries, for examples elements from Andalusian architecture meets with the Fatimid, Mamluk, and Ottoman, etc. Palace of the Shawarbi (Palace of Deglion Delor 1289-1872) considered one of the most remarkable examples of this. The revival of the Islamic style was not purely Islamic architectural, but it was a pseudo-pattern where it was a mask placed on the buildings and outer shell of the buildings. It does not express the Islamic spirit, inspired by the sense of Islamic faith [32].

The second object in this study is the Egyptian Museum in Tahrir Square, Cairo. The Identification data 
of this building described in Table 3 .

Table 3: Identification Data of The Egyptian Museum in Tahrir Square, Cairo

\begin{tabular}{lll}
\hline \multicolumn{3}{c}{ The Egyptian Museum in Tahrir Square Figure 8} \\
Plate (6)
\end{tabular}

The Egyptian museum was one of the most prominent examples of the eclecticism. It is currently located in Maidan Al-Tahrir. The site was originally called the Nile Palace (Figure 9). It was founded on the first day of April 1897 A.D corresponding to Thursday, 29 Shawwal 1314 AH. Abbas Hilmi II put the first stone by the historical Egyptian Antiquities Museum and attended the celebration so Excellencies Mustafa Fahmy Pasha, Chairman of the Board of Supervisors and the headmaster of the Interior and Hussein Fakhri Pasha headmaster of works and knowledge [33]. It considered one of the most famous buildings in the age of Khedive Abbas Helmy II. In the beginning of the idea of its creation in 1857 in the era of Khedive Said. The purpose of it is to incorporate modern discoveries and excavations. It was officially inaugurated on 15 November 1902 and is considered the first building in the world to be built specifically for a museum. It was customary before this date to allocate old residential villas to any museum [34].

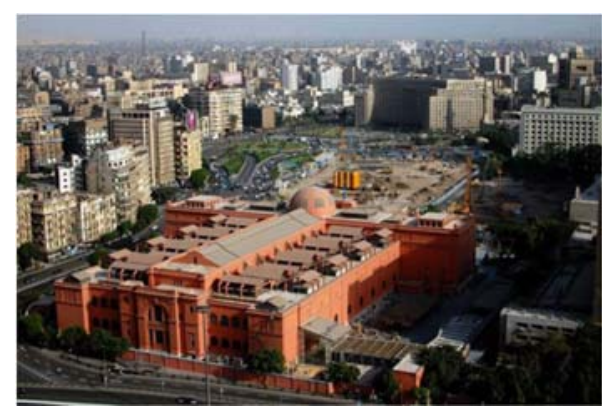

Figure 8. The general view of the Egyptian Museum in the middle of Tahrir Square, Cairo.

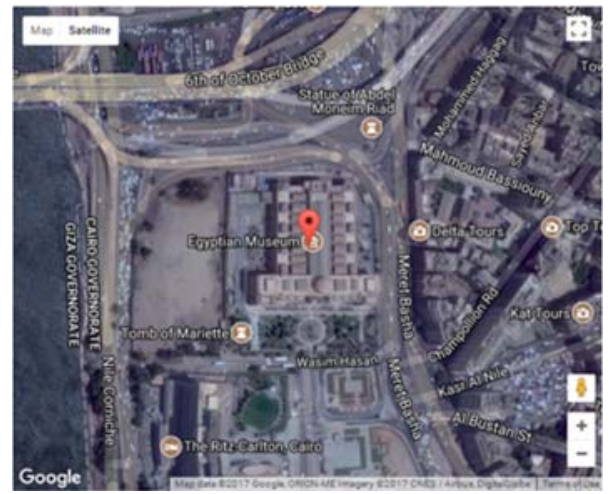

Figure 9. A map showing the location of the Egyptian Museum, Cairo. Source: Google Earth

Between 73 architectural designs competing in the museum's construction project, the design of the French architect (Marcel Dornon) was selected. While an Italian company carried out the construction of the project, the structure, designed by Dornon considered as a creative work by the standards of that period in 1897 AD where the concrete material was used for the first time in Egypt also using the latest methods of construction in this era [1].

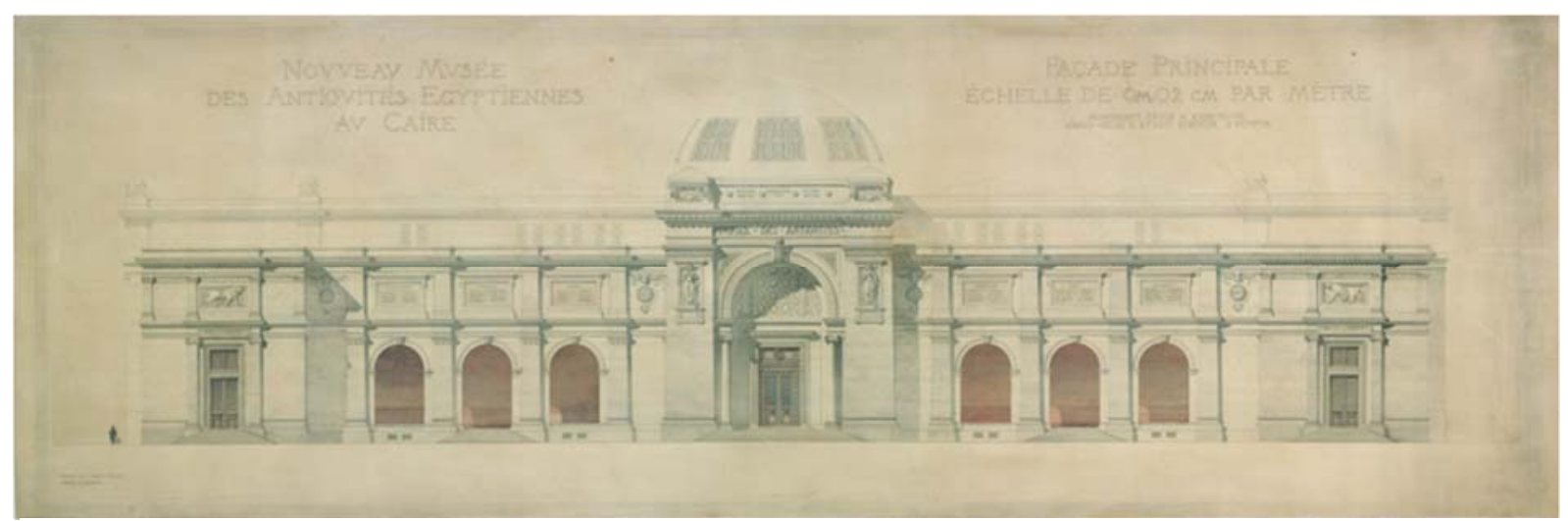

Figure 10. The horizontal section of the main façade of the Egyptian museum by Marcel Dourgnon. Source : http://archimedori.hypotheses.org/13

This building is considered as an eclectic example of both European neo-classical and stylized neo-Pharaonic styles. The external architecture of this museum consists of four stone facades; the first is the main façade in the south-east as in figure 10, with the main entrance in the middle. The main entrance portal is higher than the rest of the façade besides the corner bays which emphasized the symmetry and axiality of the building, as in figure 11. It consists of a semicircular entrance (Figure 12). In the middle door, a stone lintel decorated by a circular metal medallion topped by the royal crown (Figure 13). In The top of the arch keystone, a prominent figure of an animal head in the form of the Pharaonic mother goddess Hathor topped with a cow's horn with the sun disk inside them, as in figure 14 . 


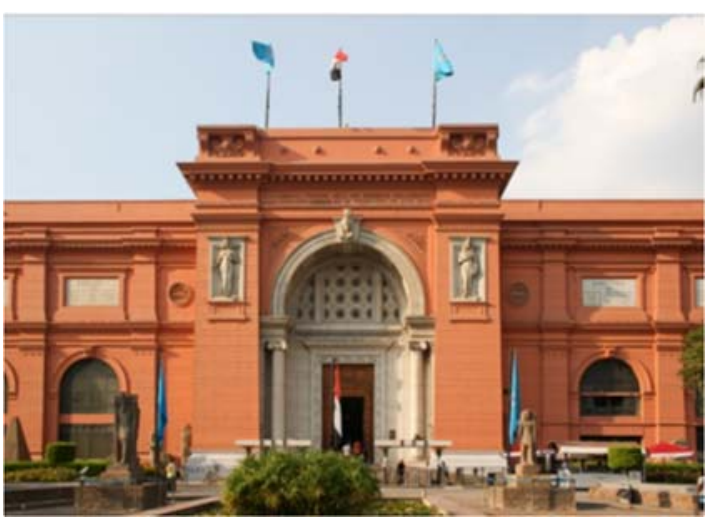

Figure 11. Main façade of Egyptian museum, the main entrance located in the middle

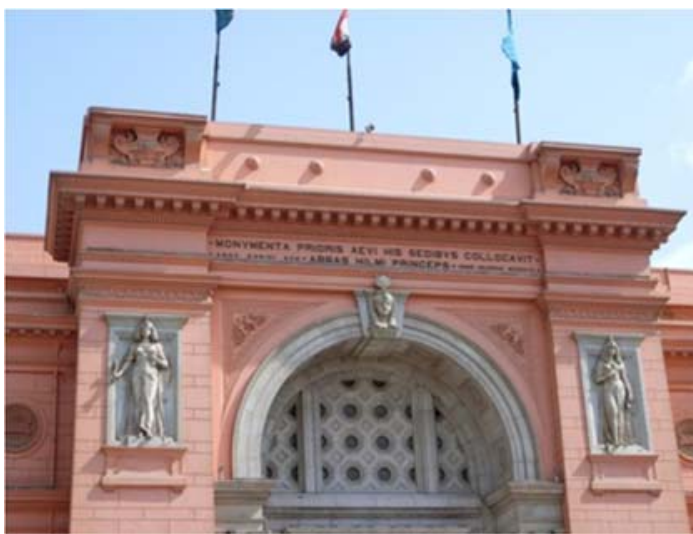

Figure 12. Details of the upper section of the Main facade of Egyptian museum indicated Pharaonic influences.

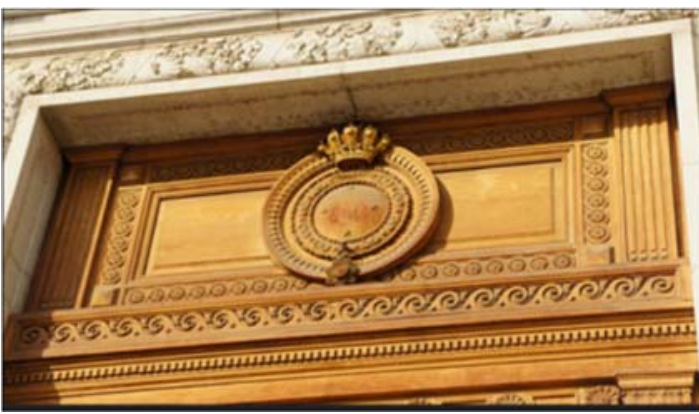

Figure 13. A circular metal medallion topped by the royal crown in the lintel of the door opening of Egyptian museum.

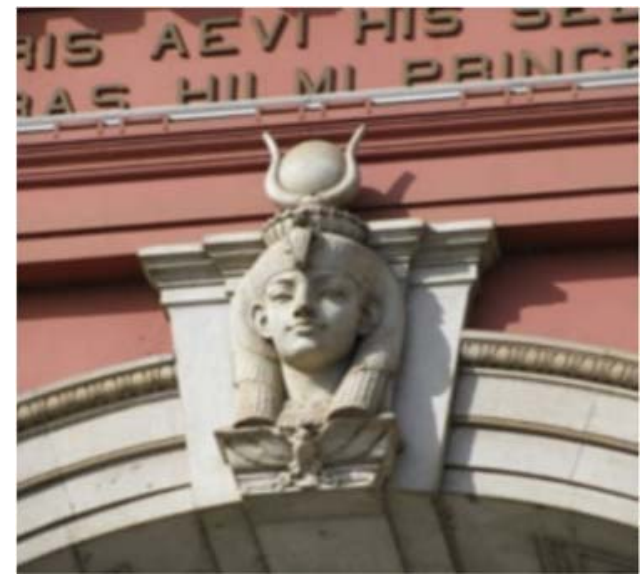

Figure 14. The figure of Pharaonic mother goddess Hathorat the top of the arch keystone. Of the main entrance of Egyptian

museum
Spandrels of the arch are decorated with two prominent triangles decorative with geometric motifs. In the middle of each triangle recorded first letters of the name Khedive Abbas Helmy II which is (A.H) in overlapping mode.

The arch of this entrance based on two cylindrical marble The museum's main entrance is flanked by two marble columns in lonic order and two female sculptures increek style personifying the goddesses of Upper and Lower Egypt.

On both sides of this decade are two statues of the goddess Isis with the Roman cloak and the wavy wig and above it, two decorative forms in the form of two royal crowns, inside the right one is the date of laying the foundation stone in 1315/1897 (Figure 15). Inside the left is the opening date of the museum in 1319/1901.

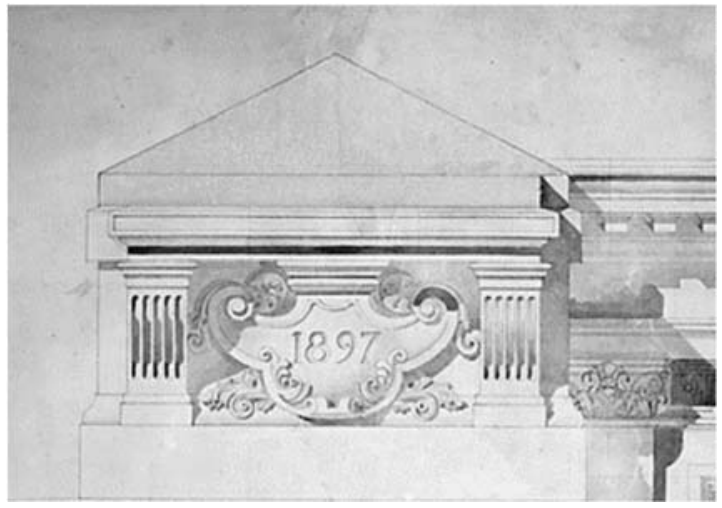

Figure 15. Egyptian museum in Cairo indicated the date of laying the foundation stone in 1897 above the main entrance. Source:https://inha.revues.org/docannexe/image/7007/img-6.jpg

On the right of this entrance are three arched niches, topped by three marble plates bearing the names of some of the ancient Egyptian and GrecoRoman flags, as well as the names of some essential Egyptian cities such as Memphis and Tanis [35].

\section{FATURES OF THE ECLECTIC ISM STYYE IN THE EG YPIIAN MUSEUM IN TAHRIR SQUARE, CAIRO}

The Egyptian Museum considered as one of the most famous buildings built in Eclecticism style. It includes a collection of architectural styles used by the Dornon.

The first main style appeared is the neoclassical style combined with Greek and Roman decorative ornaments on the façade and the French, an Italian Renaissance style. The overall organization of the museum adheres to the European neoclassical style.

Classical principles of symmetry, regularity, order, and harmony are respected, as in figure 16 . In addition to some influences from the ancient Egyptian civilization, especially in the design of its rooms and interior Halls, the entrance to the inner halls simulates mausoleum of the ancient Egyptian temples and rooms simulates the Temple of Edfu. 


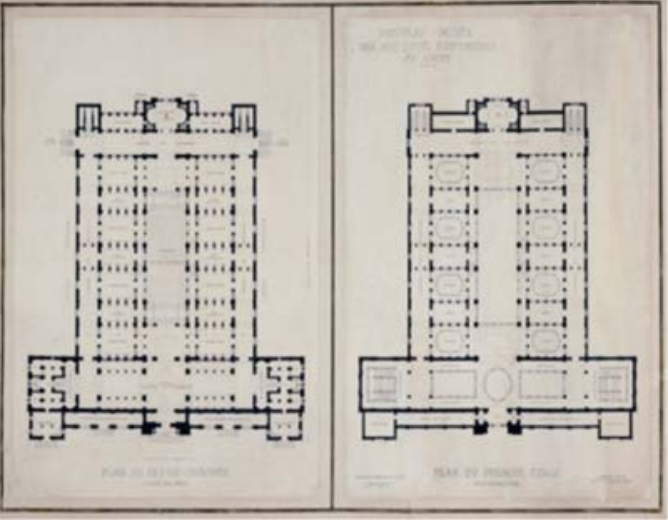

Figure 16. Plan of ground and first floor of the Egyptian museum by Marcel Dourgnon. Source,https://inha.revues.org/docannexe/ image/7007/img-1-small580.jpg

The neoclassical style appeared in the symmetrical and similar in planning and the facades, also in the use of frames and cornices at the ends of the walls as a kind of architectural treatments. These cornices include some Greece and Roman decoration like the decoration of egg and arrow and decorations of intentions and teeth. The stucco motifs decorations were also extensively used for stucco statues which decorated keystone of the arch opening of the entrance. For example, there is a statue of one of the Pharaonic gods. On both sides, there are two statues of a Pharaonic form in a classical method as in figure 17 $\& 18$ [12].

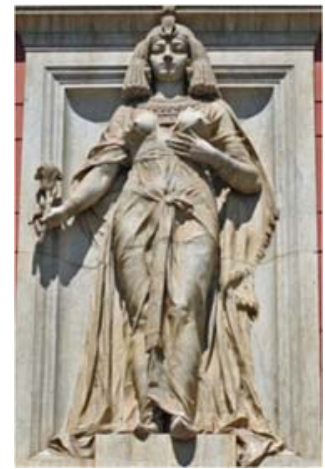

Figure 17. The Egyptian museum, A Pharaonic statue in a classical method on the right side of the main entrance. Source : http:// www.ehabweb.net/wp-content/uploads/2012/06/070311-747.jpg

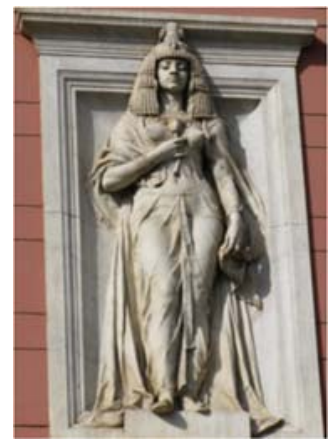

Figure 18. The Egyptian museum, A Pharaonic statue in a classical method in the left side of the main entrance. Source : https://.pinimg.com/736x/a7/26/07/

a72607d53edb5565b0757d1a76e25376--cleopatra-history-artsculptures.jpg
The last building object in this study is El-Baron Emban Palace in Heliopolis known as Hindu temple. The Identification data of this building described in Table 4 .

Table 4: Identification Data of El-Baron Emban Palace in Heliopolis, Cairo

El-Baron Emban Palace in Heliopolis known as "Hindu temple" (Figure 19)

Address: 17 El Orouba St., Salah Salem Extension [27] (Figure 20)

\begin{tabular}{|c|c|c|}
\hline $\begin{array}{l}\text { archeological number: } \\
\text { None }\end{array}$ & $\begin{array}{l}\text { Date of } \\
1323-1327 \\
A D\end{array}$ & $\begin{array}{l}\text { construction: } \\
\mathrm{AH} / 1906-1909\end{array}$ \\
\hline $\begin{array}{l}\text { Creator Name: } \text { Eduard } \\
\text { Louis Joseph, Baron } \\
\text { Empain }\end{array}$ & \multicolumn{2}{|c|}{$\begin{array}{l}\text { kind: Palace - residential } \\
\text { building }\end{array}$} \\
\hline $\begin{array}{l}\text { Status of Monument: } \\
\text { exit }\end{array}$ & $\begin{array}{l}\text { Adminis- } \\
\text { trative } \\
\text { Area: Heli- } \\
\text { opolis }\end{array}$ & $\begin{array}{l}\text { Archaeo- } \\
\text { logical } \\
\text { Area: } \\
\text { North } \\
\text { Cairo }\end{array}$ \\
\hline
\end{tabular}

This palace is one of the outstanding architectural examples and has a great historical value. It is famous for its uniquely beautiful architecture. Eduard Louis Joseph built it. Meanwhile, Baron Empain, the wealthy Belgian industrialist who founded the city of Heliopolis to be similar to the Taj Mahal in India, as he was grateful to the people of India for caring for him during his illness there on one of his visits to India.

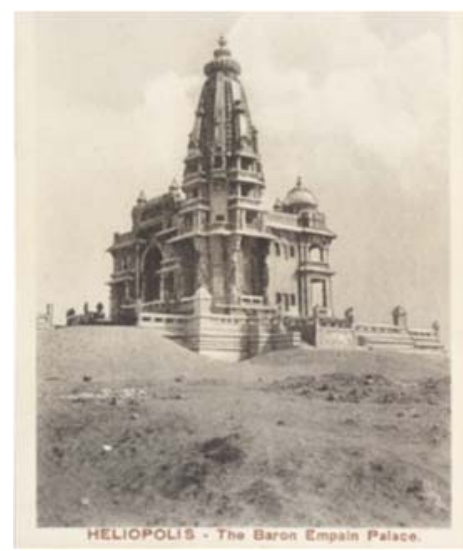

Figure 19. El-Baron Emban Palace - an archival image showing general view located in Heliopolis. Source : http:// www.archivegypt.com/wp-content/uploads/HELIOPOLIS__The_Baron_Empain_Palace_n.d._-_front_-_TIMEA.jpg

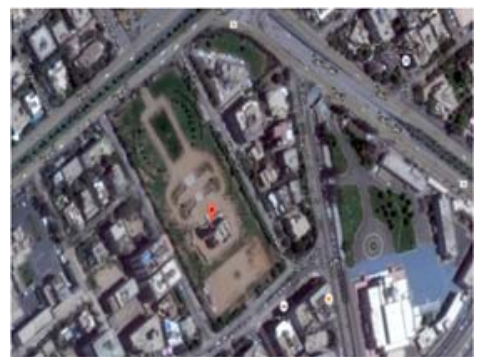

Figure 20. A map showing the location of El-Baron Emban Palace in Heliopolis, Cairo Source: Google Earth 
It was built five years ago and was designed so that the sun would not miss it. It was made on a concrete base based on Rollman Bell, which rotates on moving wheels. The palace is surrounded by about six acres. The castle is considered a rare masterpiece in Indian style architecture. It consists of two floors of six large rooms and two halls and a small extension near the roof and beneath the palace are underground chambers (Figure 21). On the north of the castle is a large four-story tower with a spiral staircase of wood (Figure 22).

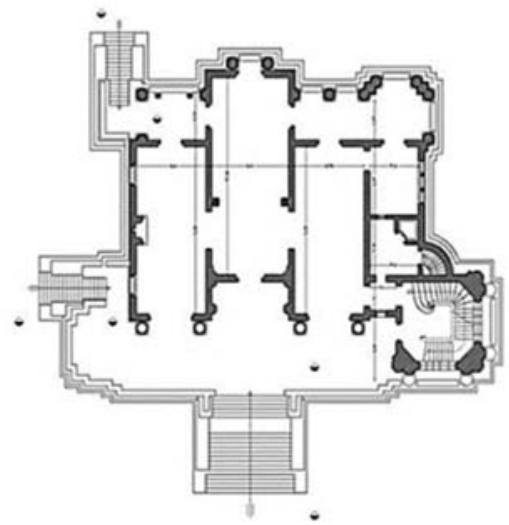

Figure 21. Plan of the first floor of El-Baron Emban Palace. Source: Center for registration of Islamic and Coptic monuments in Cairo

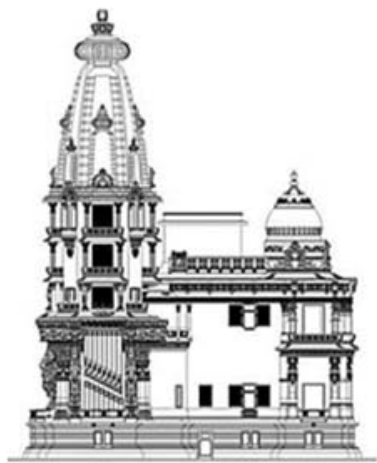

Figure 22. Vertical Section of El-Baron Emban Palace indicated the huge tower influenced by Hindu temples. Source: Center for registration of Islamic and Coptic monuments in Cairo

At the entrance to the palace, there is a collection of marble and stone statues with human and animal forms. Also, the façade of the castle is decorated with geometric, floral motifs and concrete sculptures of Hindu deities, snakes, elephants, mythical creatures, and dancers, Buddhas, Shivas and Krishnas (Figure 23).
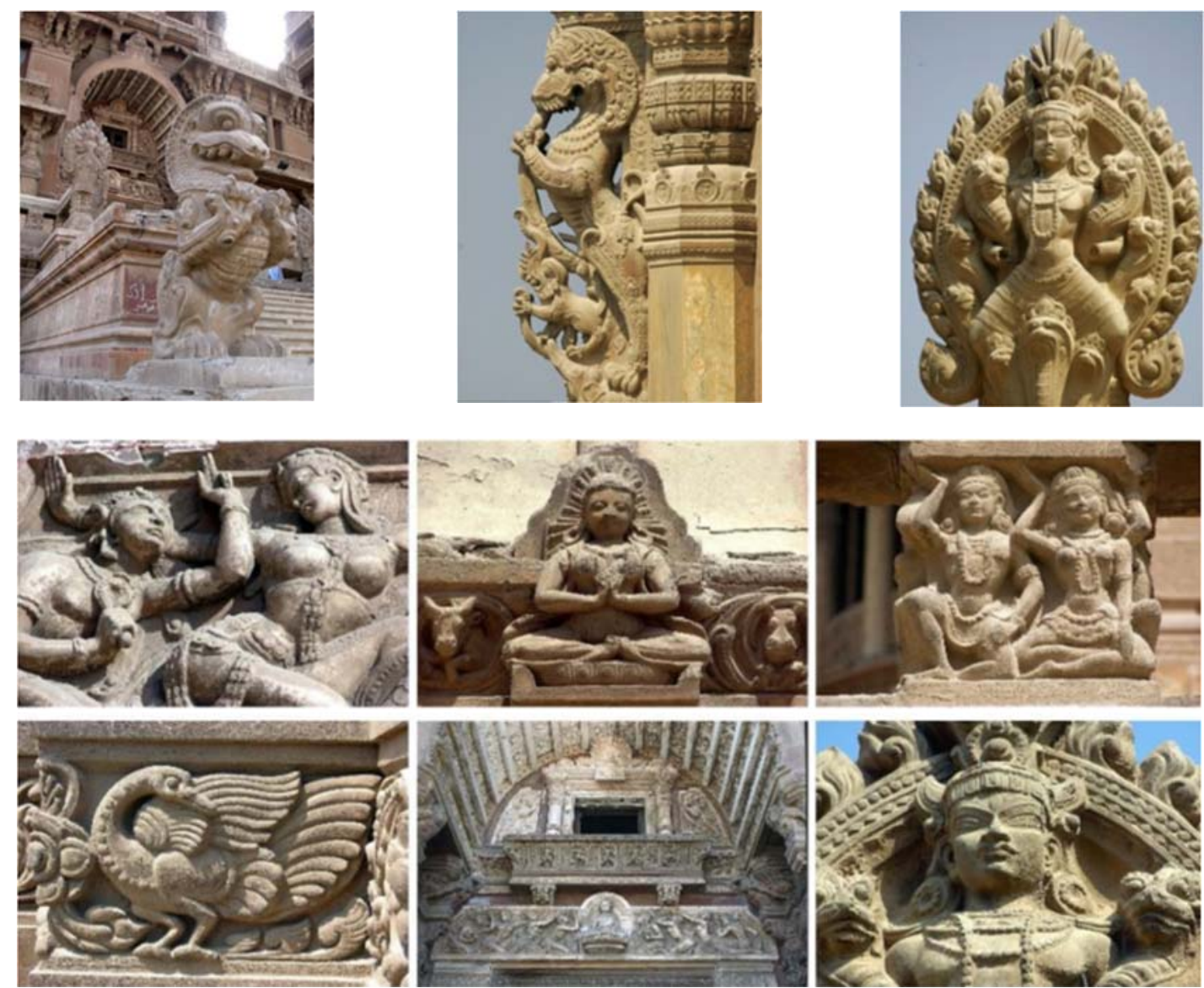

Figure 23. Details of sculptures of Hindu deities, snakes, elephants, mythical creatures, and dancers, Buddha's, Shiva's and Krishna decorated different facades and balcony of El-Baron Emban Palace. Source: author. 
When Hassan Kamel became a ruler over Egypt, he admired this palace and asked Baron to guide him. But the Baron refused, and in an attempt to please the Sultan, Baron set up another palace opposite to his castle, but not the same style. Then he gave it to the Sultan.

But the Sultan refused and was angry at the Baron, so the Baron found no solution but to leave Egypt, then Sultan died, and Baron also passed away before the arrival of Egypt in Belgium in 1929, but his body was brought back to Egypt for burial under the Catholic Basilica of Notre Dame in Heliopolis.

His son inherited the palace, but he neglected it and was sold with the public auction in 1905 A.D. Until he issued a decision by the Egyptian Prime Minister to consider the mansion an Islamic monument.

\section{FEATURES OF THE ECLECTIC ISM STYYE IN E- BARON EMBAN PALACE, HEJOPOUS}

This Palace is considered as an architectural and artistic masterpiece, as it combines between many ancient civilizations, Hindi, Greek, Persian, European and Roman. Emban chose a high altitude east of Cairo to be a place for the palace on the desert road.

He wanted the castle to be a strange and different design. He made the walls in different shapes. On the walls, there are statues of marble elephants, mythical animals, and heroes with swords.

The palace design is Indian style; it was designed by the French architect Alexandre Marce [24] (1860-1928), and Marcel's colleague Georges-Louis Claude (1879-1963) designed the interior and made decoration, architect Alexandre [36] was inspired by the Hindu temple of Angkor Wat in Cambodia and the Hindu temples of Orissa in India. So, this palace was known by locals (The Hindu Villa).

It is Famous with its long crown decorated with Buddha statues, was like an Indian temple built of reinforced concrete, Balconies of the palace are mounted on statues of Indian elephants and the windows studded with Belgian glass were specially created so as never to lose sight of the sun.

They rise and fall with Indian and Buddhist statues on the right side. Marbles of the palace were imported from Italy and the crystal from Czechoslovakia. Gothic style was used in the use of the towers, and elements of the Neo-Islamic style were appeared in the main entrance to the palace as in figure 24 [24].

Also, Renaissance style emerged in the Palace which is shown in some statues, besides the main door they have Roman features resembling the Greek and Roman knights (Figure 25).

The interior design of the palace is European style, and walls of the castle decorated by paintings from Michelangelo, Leonardo da Vinci and Rembrandt, also gilded ceilings, parquet floors, gold-plated doorknobs went and the famed Belgian mirrors [37] [38].

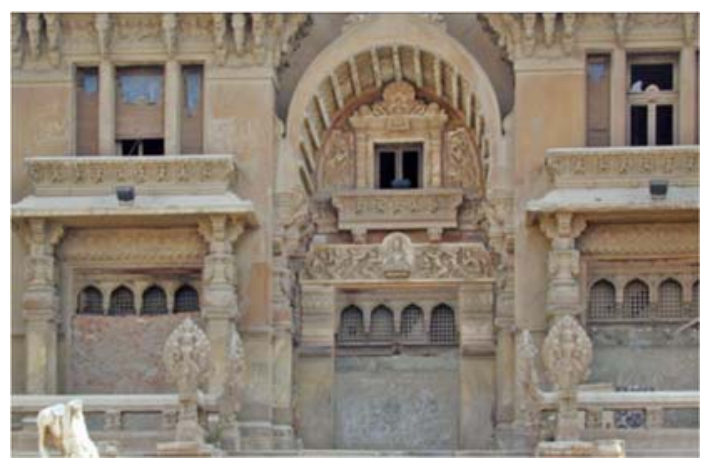

Figure 24. El-Baron Emban-The northwestern façade, with the main entrance in the middle, indicated Islamic influences inWood -cutting above the door decorated with engraved reliefs with floral motifs. Source: author

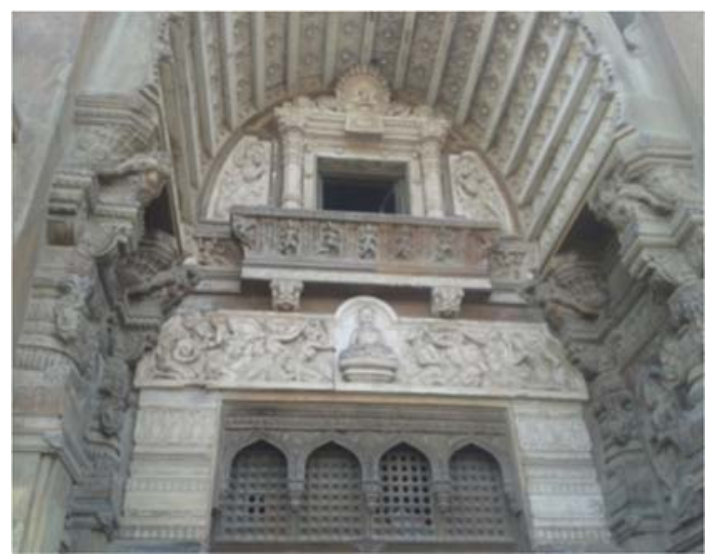

Figure 25. El-Baron Emban - Details of decorations the main entrance, It is crowned with a panel decorated with a prominen engraving with the statue of the god Buddha on the middle. Source: author

\section{CONCLUSION}

In this study, the researcher studied a new type of European style, which spread in Egypt during the 19th century and the beginning of the twentieth century. It is Eclecticism style, which is the selection of architectural elements from each of the previous historical buildings and reintegrating them according to needs. It postulated a combination of a variety of European styles such us Neo-Classical style which founded nearly in all examples which Classical principles of symmetry, axiality, regularity, order, and harmony are respected. There are a lot of variously stylized cornices such us crenellations, neo-baroque, neoclassical, gothic spires Corbeled parapet and treatments. Also using of separate and continues projecting balconies upon brackets.

Use of towers, domes, rounded corners which is familiar in gothic architecture. Such as the building of Matafi al qahira which the most distinguishing features are the two towers: the octagonal and three-quarter round engaged corner one. Also, the Mediterranean style appeared in this building in the use of continues cornice composed of a serious of corbeled arches above the second floor and in using different types of segmental arched windows.

A lot of Islamic features appeared in these examples such as the Ablaq decoration using red and 
yellow alternating courses such as in facades of The French Catholic Al-Qiddis Yusuf church. A lot of Pharaonic features also appeared in these examples such as Pharaonic goddess figure and statues in Egyptian museum. So, eclectic style is the combination of different stylistic European and traditional features (Islamic - Pharaonic .etc) in one building.

This study finds that the term Eclecticism as stated in this study means selectivity or selectivity to choose better to output a distinctive model. Perhaps the primary purpose of this quotation and transportation is to give historical and technical value to these monuments. But unfortunately, the way and method of this quotation came in the wrong direction because these old styles arose under the influence of factors and circumstances that differed from the conditions that existed in the period of the buildings which wanted to be designed on these styles. Thus became a superficial appearance and details taken from architectural works from ancient times applied or affixed as a mask on buildings that do not belong to those ages and are not related to them. They unwittingly distorted the heritage value. These buildings became a collection of models that are not harmonious. Unfortunately, the Eclecticism spread in its ugly face in the city of Cairo in all aspects of life, architecture, art or even the customs that we quoted blindly from the West, which we looked at with great admiration, admiration, and pride. And we have forgotten that the East, and especially the Muslim Arabs, had a head start in all fields of civilization, and Europeans learned from Arabs then they woke up and made the age of their renaissance.

\section{REFERENCES}

[1] I. M. Eldemery, "Globalization Challenges in Architecture," J. Archit. Plan. Res., vol. 26, no. 4, pp. 343-354, 2009.

[2] A. M. Salama, "Mediterranean visual messages : the conundrum of identity, isms, and meaning in contemporary Egyptian architecture," ArchNet-IJAR Int. J. Archit. Res., vol. 1, no. 1, pp. 86-104, 2007.

[3] S. Kaji-O'Grady, "Authentic Japanese architecture after Bruno Taut: the problem of eclecticism," Fabr. J. Soc. Archit. Hist. Aust. New Zeal., vol. 11, no. 2, pp. 1-12, 2012.

[4] M. Carpo, "Architecture: Theory, Interdisciplinarity, and Methodological Eclecticism," J. Soc. Archit. Hist., vol. 64, no. 4, pp. 425-427, 2005.

[5] V. Pachta and I. Papayianni, "The Study of the Historic Buildings of Eclecticism in Thessaloniki Under the Prism of Sustainability," Procedia Environ. Sci., vol. 38, pp. 283-289, 2017.

[6] M. A. O. Khali, "Reflections of the cultures of architecture and architecture in Egypt with special mention For the city of Cairo (suburb of Maadi)," University of Cairo, 1997.

[7] D. Behrens-Abouseif and S. Vernoit, Islamic Art in the 19th Century, Tradition, Innovation, and Eclecticism. Leiden: Brill, 2006.

[8] B. Szmygin, How to assess Built Heritage? Assumptions, Methodologies, Examples of Heritage Assessment Systems. Lubin: International Scientific Committee for Theory, Philosophy of Conservation and Restoration ICOMOS, 2015.

[9] T. M. Seebohm, "Naturalism, Historism, and Phenomenology," Adv. Phenomenol., vol. 62, pp. 7-32, 2010.

[10] J. M. Dillon and A. A. Long, The Question of "eclecticism": Studies in Later Greek Philosophy. University of California press, 1988.

[11] W. Craft, A history of Russian architecture. New York: Cambridge University Press, 1993.

[12] M. kamal Al Kandil, "An analysis of architectural styles in Cairo downtown 1863-1914," Cairo University, 2000.

[13] A. Whittick, European Architecture in the Twentieth Century. 1st Ed. New York: Leonard Hill Books, 1974.

[14] F. Dostoevsky, A Writer's Diary Paperback. Abridged, 2009

[15] E. E.-D. Abdel Raouf, "Trends of Egyptian Architecture from Heritage to Contemporary," Al-Azhar University, 1976.

[16] A. M. S. Najm, Palaces of Princes and Pashawat in the City of Cairo in the 19th Century, Part II. 2002.

[17] B. Fletcher, A History of Architecture on the Comparative Method, 17th Edition, 17th ed. London: Charles Scribner's Sons, 1967.

[18] H. Abdel Wahab, "The Movable antiquities of Islamic Architecture,” J. Egypt. Acad. Sci., pp. 243-283.

[19] T. Okasha, The aesthetic values in Islamic architecture, 1st ed. Cairo: Dar al-Shorouk, 1994.

[20] I. Hosny, "The European Cultural Connection," Knowledge World Magazine, kuwait, p. 28, 2009.

[21] I. Sami, Theories of Architecture, First Year

94 | Journal of Islamic Architecture, 5(2) Desember 2018 
Course for Architecture Students. United Color Printing Press, 1967.

[22] A. Raymond, Cairo History and Civilization. Dar AL-Fekr.

[23] R. S. Sennott, Encyclopedia of Twentieth Century Architecture VOLUME 1 A-F. New York: FITZROY Dearborn, 2004.

[24] A. Dubrovolsk and Y. Dubrovolski, Heliopolis The city of the sun is reborn. Cairo: Egyptian General Book Authority, 2008.

[25] C. Minti, Cairo Ismail Paris on the banks of the Nile. Cairo: National Center for Translation, 2008.

[26] H. Abu Jalil, Cairo Streets and Tales. Cairo: Egyptian General Book Authority, 2011.

[27] M. of Culture, Supreme Council of Antiquities, Guide to Islamic Antiquities in Cairo, first edition. press of the Supreme Council of Antiquities, 2000.

[28] Y. Tabbaa, "Andalusian Roots And Abbasid Homage In The Qubbat Al-Barudiyyin In Marrakech," Muqarnas, vol. 25, pp. 133-146, 2009.

[29] A. Sumi, "Poetry and Architecture: A Double Imitation in the Siniyyah of Ahmad Shawqī," J. Arab. Lit., vol. 38, no. 1, pp. 72-122, 2008.

[30] N. Cherif-seffadj, "THE MEDIEVAL AND OTTOMAN HAMMAMS OF ALGERIA ; ELEMENTS FOR A HISTORICAL STUDY OF BATHS ARCHITECTURE IN NORTH AFRICA
Nabila Cherif-Seffadj," Archnet-IJAR, Int. J. Archit. Res., vol. 3, no. 1, pp. 157-170, 2009.

[31] K. Azab, Sultanate Dar in Egypt Architecture and Political Transformation,. Cairo: Supreme Council of Culture Press, General Authority for Printing amiri Press, 2007.

[32] A. E. M. S. Najm, Palaces of Princes and Pashawat in the city of Cairo in the nineteenth century. 2002.

[33] E. Gady, "Le Musée des Antiquités du Caire : un lieu de mémoire pour les Egyptiensou pour les Occidentaux, , Fait partie d'un numérothématique : Sites et moments de mémoire," Année, vol. 93, no. 350, pp. 81-90, 2006.

[34] F. H. Al Hadidi, Historical Assets of State Institutions and Public Utilities in Cairo. Cairo: Dar Al Ma'aref, 2007.

[35] A. Rizk, Atlas of Islamic and Coptic Architecture in Cairo, vol. 4, 1st ed. Madbouli Library, 2003.

[36] M. Volait, Le Caire-Alexandrie architectures européennes, 1850-1950, Centre d'études et de documentation économique. juridique et sociale, Institutfrançais d'archéologie orientale, 2001.

[37] S. Z. Hawas, Khedive Cairo Monitoring and Documentation, architecture and building of area Downtown Center. Cairo: Center for Architectural Design, 2002.

[38] Z. Hawas, "Baron Emban Palace," Al Arabiya Magazine, 2014. 